ARQGA/1137

\title{
HABILITAÇÃO OU PROFICIÊNCIA?
}

DESCRITORES - Colonoscopia. Competência clínica.

Segundo estimativas do Instituto Nacional de Câncer (INCA) para 2003, a incidência e a mortalidade do câncer colorretal foram de, respectivamente, 20 e 10 casos para cada 100.000 brasileiros, cifras apenas superadas por pulmão, pele, estômago, próstata, mama e colo do útero (www.inca.gov. br/estimativas/2003).

Estas cifras, ainda maiores na América do Norte, têm levado ao desenvolvimento de estratégias de rastreamento populacional para detecção da neoplasia. Uma delas consiste na indicação de, ao menos, um exame de colonoscopia a partir dos 50 anos de idade, em indivíduo assintomático, sem antecedentes familiares de câncer colorretal ou síndrome de polipose. Este modelo também foi adotado em nosso meio, através da iniciativa de sociedades médicas e associações, fazendo chegar esta informação ao grande público. À semelhança do que vem ocorrendo com nossos colegas do hemisfério norte, prevê-se aumento significativo da agenda de exames de colonoscopia no setor público e privado ${ }^{(5)}$. Neste sentido, obvia-se a importância do ensino da técnica de colonoscopia, bem como torna-se fundamental a determinação de parâmetros que avaliem a capacitação destes profissionais recém-formados ${ }^{(4)}$.

Dentre as várias particularidades do exame colonoscópico, duas podem ser destacadas: a primeira se refere à incapacidade inerente ao exame de permitir a análise de $100 \%$ da superfície mucosa colônica. Tratando-se o cólon de órgão tubular, de trajeto tortuoso, sanfonado pela presença de tênias, e o aparelho de colonoscopia, de visão frontal, há regiões de difícil acesso à observação do examinador; a segunda particularidade se refere à técnica de inserção do aparelho até o ceco. Esta é naturalmente prejudicada pelo fato de os cólons sigmóide e transverso possuírem meso e conseqüente mobilidade, e pelo fato da relativa flexibilidade do tubo de inserção do colonoscópio. Assim, para os examinadores incipientes é comum a introdução de quase todo o aparelho, sem que se progrida além do cólon esquerdo, às custas, é claro, de sensação dolorosa bastante desagradável para o paciente, provocada pela distensão do mesentério da alça móvel e de conseqüente risco de perfuração. Assim, as primeiras colonoscopias foram realizadas sob radioscopia, o que permitiu ao operador realizar manobras para corrigir ou evitar o acomodamento do aparelho em segmentos colônicos móveis e distendidos ${ }^{(1)}$. Com o tempo, percebeu-se que havia um certo padrão de formação dessas alças e que, com manobras pré-determinadas, era possível prosseguir até o ceco sem auxílio da radioscopia. Assim, nos dias de hoje, o colonoscopista proficiente associa essas manobras com destreza e rapidez, permitindo a inserção do colonoscópio até o ceco, em menos de 10 minutos, com o mínimo de desconforto para o paciente, em cerca de $90 \%$ dos casos. Com auxílio de colonoscópio pediátrico, outros $5 \%$ a $7 \%$ dos casos serão resolvidos. Contudo, mesmo o examinador mais experiente, dispondo de todas as variedades de equipamentos, terá que amargar $2 \%$ a $3 \%$ de casos em que aderência pós-operatória, actínica, ou distorção provocada por doença diverticular impedem a progressão do aparelho até o ceco.

Ensinar a evitar a formação de alças, identificá-las e reduzi-las não são tarefas fáceis. Aprendê-las, tampouco. É exatamente esta a mensagem que THULER et al. ${ }^{(4)}$ enviam através do artigo publicado neste número dos ARQUIVOS de GASTROENTEROLOGIA. Mesmo tutorados por examinadores experientes, dois residentes atingiram o ceco, sem ajuda, em apenas $60 \%$ e $70 \%$, respectivamente, dos primeiros 72 exames. Após 100 procedimentos, um dos residentes aumentou sua eficácia para $91,5 \%$ e reduziu o tempo médio de inserção do aparelho de 20 para 15 minutos. Assim, esses autores que pertencem a hospital universitário de perfil de atendimento terciário, validam, em nosso meio, a impressão de colegas norte-americanos de que 100 exames de colonoscopia não traduzem, nem de longe, proficiência na técnica de colonoscopia.

Em toda curva de aprendizado, o aprendiz ganha capacitação lentamente, quando então, segue-se uma fase de ascensão rápida. É neste momento que o aluno adquire confiança, pois a ele parece que a técnica está dominada. É aí então que os acidentes ocorrem. Provavelmente, para a maioria dos aprendizes, o número de 100 colonoscopias se encontra em algum ponto no meio desta fase de ascensão rápida, certamente ainda com longo percurso a ser percorrido até que se chegue ao momento em que a curva tende a se retificar. É quando o colonoscopista, mesmo após vários exames, incrementa pouco a sua proficiência. Assim, pode-se considerar que são necessários mais de uma centena de procedimentos para que a maioria dos aprendizes ganhem sua habilitação em colonoscopia, isto é, realizar exames sem tutoria. Por outro lado, a proficiência só se adquire com o tempo.

O colonoscopista experiente realiza as diferentes manobras de inserção, dependendo da sensação, do "feedback", que 
ele percebe através da rigidez do tubo de inserção e da dificuldade em introduzi-lo. Isto explica, em parte, a dificuldade do ensino em colonoscopia, uma vez que o aprendiz tem de experimentar, ele próprio, esta sensação. Este raciocínio é suportado pela evidência de que simuladores computadorizados de exame de colonoscopia que não enviam mensagens de "feedback" para o aprendiz, não aceleram a curva de aprendizado dos mesmos ${ }^{(3)}$.

Por outro lado, assunto pouco discutido é a maneira de se ensinar a técnica de inserção em colonoscopia. Há passos que parecem óbvios no cumprimento desta tarefa: sedimentar conceitos teóricos - assistir a registros e acompanhar vários exames - retirar o aparelho e, finalmente, inserir o colonoscópio. É possível que nesta última fase falte ainda alguma estratificação. Negociar a passagem do colonoscópio através do cólon sigmóide é, sem dúvida, a fase mais difícil do exame e a "chave" para o sucesso. Assim, esta dificuldade deveria ser oferecida ao final de tudo. Na prática, parece útil deixar o tutor introduzir o aparelho até a flexura hepática e, a partir daí, solicitar ao aluno que introduza até o ceco. O próximo passo é fazê-lo a partir da flexura esplênica e, somente em exames ulteriores, permitir que o aluno insira o aparelho desde o começo. Com isto, o aprendiz terá dominado movimentos básicos em situações mais simples e poderá aplicá-los na passagem através do cólon sigmóide.

Finalmente, vale a pena destacar que aqueles que ocupam as posições de mestre e aluno da técnica do exame de colonoscopia nunca devem se esquecer de que a figura mais importante neste cenário continua a ser o paciente. Deve-se, a todo custo, minimizar o risco, a dor e o tempo de exame durante o processo de ensino da colonoscopia.

Fauze MALUF-FILHO*

Maluf-Filho F. Credentialing or proficiency? Arq Gastroenterol 2004;41(4):209-10.

HEADINGS - Colonoscopy. Clinical competence.

\section{REFERÊNCIAS BIBLIOGRÁFICAS}

1. Mahmood T, Darzi A. The learning curve for a colonoscopy simulator in the absence of any feedback: no feedback, no learning. Surg Endosc 2004;18:1224-30.

2. Thuler FPBM, Di Sena VO, Hervoso CM, Libera ED, Ferrari AP. Quantos exames são necessários para adquirir aptidão em colonoscopia? Arq Gastroenterol 2004;41:211-4.
3. Twombly R. Recommendations raise workload issues for colon cancer screening. J Natl Cancer Inst 2004;96:348-50.

4. Wilkins T, Jester D, Kenrick J, Dahl J. The current state of colonoscopy training in family medicine residency programs. Fam Med 2004:36:407-11.

5. Wolf WI. Colonocopy: history and development. Am J Gastroentrol 1989;84:1017-25

*Serviço de Endoscopia Gastrointestinal do Hospital das Clínicas da Faculdade de Medicina da Universidade de São Paulo. 